\title{
Corporate Social Responsibility (CSR) and the impacts on impulse buying behavior: A literature review
}

\author{
Nguyen Truong Son ${ }^{1 *}$, Phan Thi Nga ${ }^{1}$, Tran Thi Hieu Thuan ${ }^{1}$ \\ ${ }^{1}$ Eastern International University, Vietnam \\ *Corresponding author: son.nguyentruong@eiu.edu.vn
}

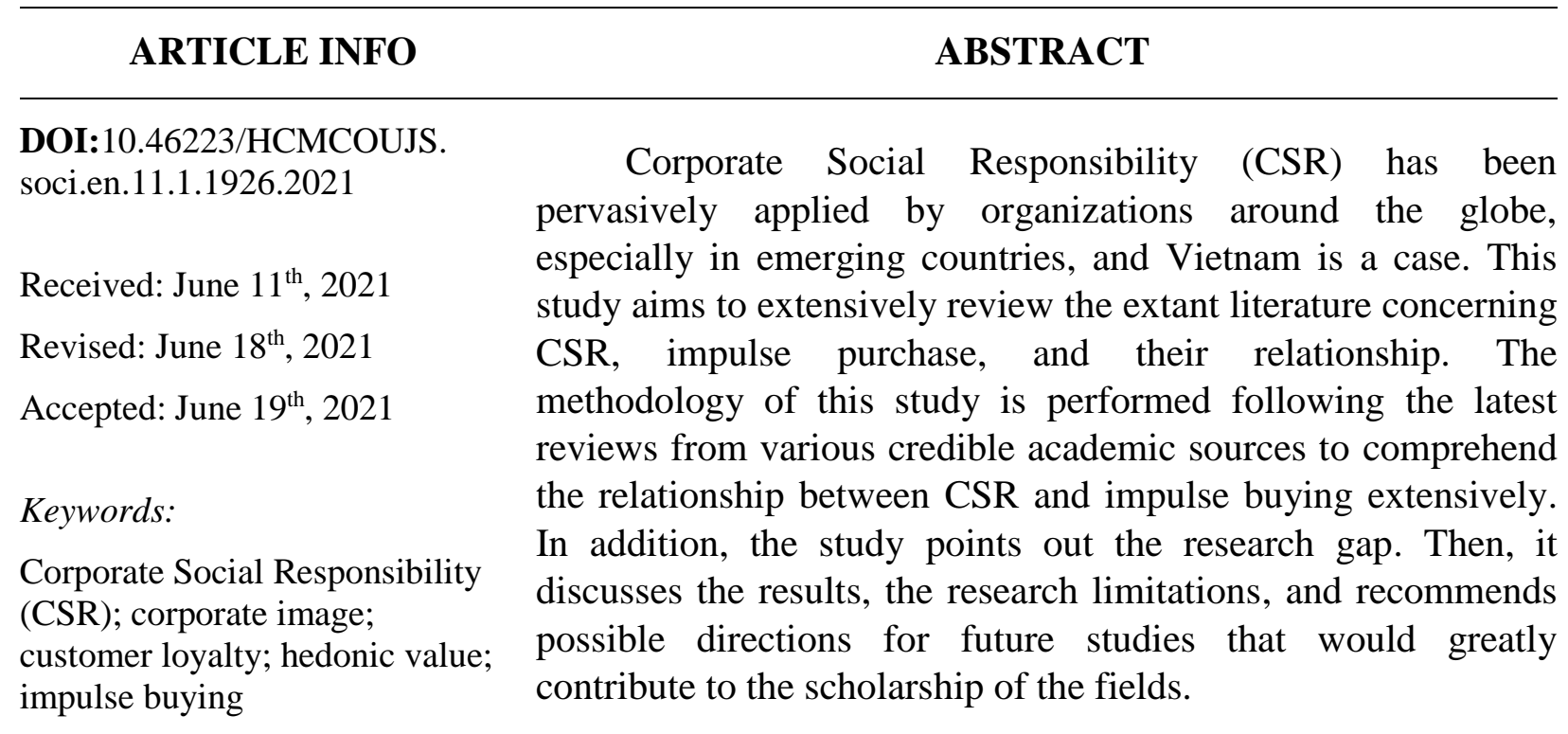

\section{Introduction}

The concept of Corporate Social Responsibility (CSR) nowadays is more and more popular in business development and becoming one of the major preoccupations of organizations around the globe. The term is generally determined as "the social contribution" of corporations towards the community. Instead of focusing on maximizing profits as companies did in the past, modern business leaders are increasingly ramping up their CSR activities to achieve sustainable development. As such, not only the companies' performance but also the way they deal with environmental and social impacts, namely the CSR performance that attracts the organizational stakeholders, including also customers (Hategan, Sirghi, Curea-Pitorac, \& Hategan, 2018). Many large organizations now consider CSR as a "new measurement of corporate performance" (C. Y. Chung, Jung, \& Young, 2018).

Over the years, the magnitude of CSR has been determined through many studies, as does the dimensions of CSR. For example, while Rahman (2011) determined up to 10 critical dimensions of CSR (obligation to the society, improving the standard of living, economic development, law-abiding, etc.), Carroll (2015) emphasized that CSR broadly covers various aspects such as economic, legal, ethical and philanthropic areas.

In developed countries, CSR practices have been becoming the core strategies of organizations for several decades. The social requirements of corporations are increasing over the years and becoming even more complicated. Citizens in developed countries look for highquality products from corporations and the organizations' ethical and moral responsibility towards the community, particularly in environmental issues, living standards, and healthcare systems. To compete effectively against other rivals and develop sustainably in business, corporations need to focus on the quality of public relations through the organization's reputation and media management. Therefore, CSR initiatives are of the utmost importance for businesses 
in developed countries (E. Sharma, 2019).

Similarly, in developing nations, business leaders increasingly realize the importance of CSR practices in economic growth, both on a regional and global scale. The government and business leaders in developing countries are spearheading CSR campaigns by various methods; however, the common purpose of the methods is to concentrate on resolving local economic issues and improving the standard of living of local citizens. The key strategies include charity events, donations, supplying food and water to the poor, promoting education, enhancing local employment (E. Sharma, 2019).

In general, customers in the modern era look for not only favorable offerings (products and services) from enterprises but also the interaction between enterprises and customers through CSR activities. For this reason, CSR is nowadays considered an effective competitive strategy in all types of industries. By embracing CSR initiatives, organizations are obtaining long-term advantages in sustainable development. In both developed and less developed countries, CSR initiatives can help establish the organization's reputation, attract new customers, and increase loyalty, resulting in higher sales and profits (Creasey, 2015). Therefore, understanding the impacts of CSR activities on customers and the community where it operates is critically essential. Although there has been a tremendous amount of research on CSR and its impacts on the business, there is a lack of CSR's studies and the relationship with the impulsive buying behavior's determinants. Thus, the field that receives considerable attention from consumers and businesses is overlooked in this day and age. Therefore, this calls for further investigations on this relevant study in order to fill this gap by aiming the contexts such as developing countries such as Vietnam that may provide greater clarity to the association between two CSR's variables and the interesting mysterious phenomenon of consumers, namely impulse buying behavior.

This study aims to extensively review the extant literature concerning CSR, impulse purchase, and their mutual relationship. In addition, the work discusses and recommends possible directions for future studies that would significantly contribute to the scholarship of the fields: CSR and impulse buying.

\section{Review methodology}

Towards an extensive comprehension of the relationship between CSR and impulse buying, the methodology of this study is performed following the latest reviews in relevant research areas. This process started with related studies identification, suitability assessment, and conclusions generated based on the studies' findings. Then, to scrutinize the research field's juvenescence and clarify contributions not yet covered in previous journals, various keyword combinations were applied in this searching stage. Different keywords, including Corporate Social Responsibility (CSR), impulse buying, hedonic value, corporate image, and customer loyalty, were combined in the search for academic articles from various highly-trusted online databases, such as ScienceDirect, Google Scholar search engine, EBSCOhost, and host university databases where the authors establish the literature review. Additionally, several textbooks and book chapters were also considered to broaden the review focus beyond scholarly journals.

\section{Results}

\subsection{CSR: Conceptual frameworks and theories}

There are many definitions for CSR derived from previous researchers in relevant studies, varying among different issues. In the past decades, some earlier economist thinkers such as Friedman (1970) defined CSR in a very narrow view - increasing business profitability only (Carroll, 1979). This view means that the company's only responsibility is to its shareholders, not the public or society. By contrast, later researchers expanded CSR definitions 
and argued that CSR activities should go beyond the scope of economic profits and regulations. Carroll (1979) pointed out four main components of CSR, including economic, legal, ethical, and philanthropic responsibilities. According to the author's perspective, economic responsibility is the primary and foremost responsibility of business institutions. Since corporations are regulated by law, the next responsibility of organizations is to fulfill legal requirements. In addition, ethical responsibility and discretionary responsibility are also needed to be performed by corporations to make contributions to social issues. In current studies, researchers have pointed out three main CSR activities that corporations are more involved in, including social issues, economic wellbeing, and the environment (Sen \& Bhattacharya, 2001; E. Sharma, 2019).

\subsubsection{Benefits of CSR implementations}

Previous studies have indicated numerous benefits that corporations can reap from CSR campaigns (Joireman, Smith, Liu, \& Arthurs, 2015). From the perspective of Oh, Hong, and Hwang (2017), by promoting CSR activities and satisfying the needs and expectations of the organization's stakeholders, including shareholders and customers, companies can attain a higher level of success compared to other rivals. This action eventually results in higher firm value (Wang \& Li, 2016). Furthermore, Jones and Murrell (2001) also pointed out another effect of CSR activities in attracting new investors as investors believe in the corporations" "sound financial management". In the modern era, CSR should be considered as a major strategy for the sustainable development of every organization (C. Y. Chung et al., 2018).

Besides that, the CSR implementations also create influences on customers' purchase behavior. Corporations that promote CSR campaigns easily attract new customers and receive supports from existing customers, which directly impacts consumers' purchase intention (Hameed, Qayyum, \& Awan, 2018). Then, corporations can explore the brand image and reputation, improve customer satisfaction and customer loyalty (Wu, Tsai, \& Tai, 2016).

\subsubsection{Building corporate image and reputation}

One of the first benefits reaped by corporations when engaging in CSR activities is the positive corporate image and reputation (Creasey, 2015). For this reason, the primary aim of CSR campaigns is to create brand image and reputation. The term "brand image" is defined by Keller (1993) as the "concepts, feeling, and attitudes of customers holding for a brand" (p. 11) when corporations create a positive image in the public perception, they could also positively influence the customer's purchase behaviors, particularly customer purchase intention (Wu et al., 2016). Many corporations across countries have erected corporate image in the public perception and attained competitive advantages over companies based on their CSR initiatives (E. Sharma, 2019). This also means that corporations have less incentive to spearhead CSR campaigns without the benefits of a positive brand image.

As the benefits of positive brand image, implementing CSR initiatives also helps enterprises improve their reputation among various stakeholders (Hu, Chen, Shao, \& Gao, 2018). The creation of a good reputation can attract and retain customers in a positive way. Furthermore, a positive reputation can also help firms attain stakeholders' support since stakeholders often prefer to associate with organizations with a good reputation (Vidaver-Cohen \& Brønn, 2015). In general, the improvement of corporate reputation enhances its competitiveness and the firm value (Hu et al., 2018).

\subsubsection{Improving customer satisfaction and customer loyalty}

Studies have long suggested the relationship between CSR and customer satisfaction, finding out that CSR is the key determinant influencing customer evaluation of companies' products and services (Luo \& Bhattacharya, 2006). When CSR activities are done correctly, that 
can create positive impacts on customer's attitudes and generate greater customer satisfaction (Park, Kim, \& Kwon, 2017). In other words, appropriate CSR initiatives are the major source of customer satisfaction. Customer satisfaction results directly and positively in customer loyalty, which is described through the study (Park et al., 2017). This means the greater customer satisfaction corporations gained, the higher customer loyalty could be achieved (K.-H. Chung, Yu, Choi, \& Shin, 2015).

Customer loyalty is one of the key objectives of all corporations, and this should not be separated from the objective of CSR initiatives. Authors in previous studies suggested the relationship between customer loyalty with corporate performance and corporate image (Chang \& Yeh, 2017; Iglesias, Markovic, Bagherzadeh, \& Singh, 2020). CSR implementations aim to sharpen customer perceptions such as satisfaction and trust, which positively affect customer loyalty. As a result, customer loyalty increases corporate profitability, creates more "repeat transactions" with higher prices, and makes more referrals, and leads to enhances corporate performance (Iglesias et al., 2020). This result is similar to the study of Chang and Yeh (2017), indicating that the positive results of CSR activities in customer loyalty contribute to improving corporate image.

In general, the appropriate implementation of CSR activities increases customer loyalty, which leads to the growth in the overall performance of the firms (Malik, Ali, \& Ishfaq, 2015). Therefore, CSR initiatives are critically important for long-term business sustainable development, stated by Wu et al. (2016). Furthermore, the impacts of CSR implementations on customer behavior are specifically meaningful to understand, compared to other influences.

The table below shows a list of several CSR definitions/findings from other researchers in relevant studies.

\section{Table 1}

CSR: Definitions \& findings

\begin{tabular}{|c|l|l|}
\hline No. & \multicolumn{1}{|c|}{ Definitions/Findings } & \multicolumn{1}{|c|}{ Authors } \\
\hline 1 & Increasing business profitability only & Friedman (1970) \\
\hline 2 & Economic, legal, ethical, and philanthropic responsibilities & Carroll (1979) \\
\hline 3 & Satisfying stakeholders' benefits, not only shareholders' benefits & Friedman (1970) \\
\hline 4 & $\begin{array}{l}\text { Doing the right things, regardless of its impacts on enterprises' } \\
\text { performance - the moral imperative }\end{array}$ & Donaldson (1990) \\
\hline 5 & $\begin{array}{l}\text { Strategic CSR should go beyond profit maximization and create } \\
\text { benefits for the community - a component of marketing strategy }\end{array}$ & Baron (2001) \\
\hline 6 & $\begin{array}{l}\text { Treating the firm's stakeholders in an "ethical manner" or } \\
\text { "responsible manner" }\end{array}$ & Hopkins (2004) \\
\hline 7 & $\begin{array}{l}\text { Firms' actions that raise social interest, beyond firms' interests } \\
\text { and law requirements }\end{array}$ & $\begin{array}{l}\text { McWilliams, Siegel, } \\
\text { and Wright (2006) }\end{array}$ \\
\hline 8 & $\begin{array}{l}\text { Including 10 dimensions, namely, corporate economic } \\
\text { development, law-abiding, improving the living standards, } \\
\text { obligation to society, stakeholder involvement, transparency, } \\
\text { accountability, environmental issues, ethical practices, and } \\
\text { voluntary activities }\end{array}$ & Rahman (2011) \\
\hline 9 & $\begin{array}{l}\text { Including three domains, namely, social issues, economic well- } \\
\text { being, environmental issues }\end{array}$ & E. Sharma (2019) \\
\hline
\end{tabular}

Source: Collected and summarised by the authors 


\subsection{Impulse buying}

\subsubsection{An overview of impulse buying}

Impulse buying by consumers has aroused a lot of interest from researchers in the field of consumer behavior (Iyer, Blut, Xiao, \& Grewal, 2020). Impulse buying has been popularly studied in consumer behavior for more than seven years, kicked off by the study of Clover (1950), who showed the importance of impulse purchase in the retailing industry. Since then, many relevant studies regarding this area have been explored in the Western world before gaining more interest in Asian countries, especially in emerging economies, and Vietnam is a case.

As time goes on, the changing context of society has opened out various ways of defining the term (Tran, 2020). The very first study on impulse buying, conducted in the 1940s by DuPont (1965), primarily concentrated on exploring how the phenomenon happened and its scope (Aragoncillo \& Orus, 2018). A few years after the first acknowledgment, another research revealed that a significant amount of sales in retail outlets originated from unplanned purchases, emphasizing the relevance of impulsive purchasing behavior (Clover, 1950). This study was the first to conceptualize impulse buying as an unplanned purchase decision - the discrepancy between consumers' total purchases at the end of their shopping excursion and those specified as intended purchases before setting foot in the stores (Rook, 1987). Several scholars, however, have contended that categorizing impulse buying, which is merely based on unplanned purchases, is oversimplified (Kollat \& Willett, 1969; Rook, 1987; Stern, 1962). They took another step forward by arguing that, while all impulse purchases might be called unplanned, not all unplanned purchases can be termed impulsive (Aragoncillo \& Orus, 2018).

Rook (1987) re-conceptualized impulse buying as a specific behavior than a simplistic unplanned behavior by incorporating its psychological aspects, including excitement, pleasure, and irresistible urge to buy. In this sense, rather than the products, shoppers experience impulse consumption (Rook \& Hoch, 1985). Thus, Rook (1987) spiced up how previous studies characterized impulse purchasing by defining it as a persistent and strong desire to purchase goods or services instantly, which is still one of the most widely observed definitions to this day. A different definition of impulse buying proposed by Beatty and Ferrell (1998) is that it happens at the point of purchase, affected mainly by the retail environment and the consumer's mood at the time they make their purchases. Impulse buying is also described as an unplanned buying decision reflecting consumers' swift response to a stimulus whilst being accompanied by pleasant emotions (Gardner \& Rook, 1988; Youn \& Faber, 2002). In recent research of P. Sharma, Sivakumaran, and Marshall (2010b), the phenomenon was defined as a sudden and hedonic complex purchasing behavior that limits consumers' time exploring alternatives or considering future consequences resulting from its rapidity.

To sum up, as stated by Amos, Holmes, and Keneson (2014) in their meta-analysis review of literature, only when three requirements are satisfied will an impulse purchase occur: first, the purchase is unplanned and accompanied by a pleasant surge of emotions; second, the purchase's potential ramifications are not considered; and finally, it includes gratifying the individual's needs.

\subsubsection{Four domains of impulse buying in general view}

According to Stern (1962), there are four main categories of impulsive buying: (1) pure impulse buying completely disrupts the typical purchasing pattern, as it happens when the product generates emotions that consequently activates consumers' decision to buy, though they 
have no purchase intent in the first place; (2) reminder impulse buying occurs when consumers see a product in the store and decide to purchase it as it reminds them to stock up their home inventory, or simply enables them to recall a commercial and the reason why they liked the merchandise previously; (3) suggestion impulse buying takes place when consumers catch sight of an item and recognize a need that it may fulfill; and (4) planned impulse buying comes off when consumers intentionally visit a store to acquire some particular goods but also hope to make additional purchases based on promotion programs or exceptional deals that they discover at that moment.

\subsubsection{Factors that influence impulse buying}

Prior research has revealed abundant proof of factors influencing impulse buying (Iyer et al., 2020). A previous meta-analysis conducted by Amos et al. (2014) recapitulated the major impact of several determinants of consumer impulse buying and categorized them into three major classifications, namely, dispositional, situational, and socio-demographic (Figure 1).

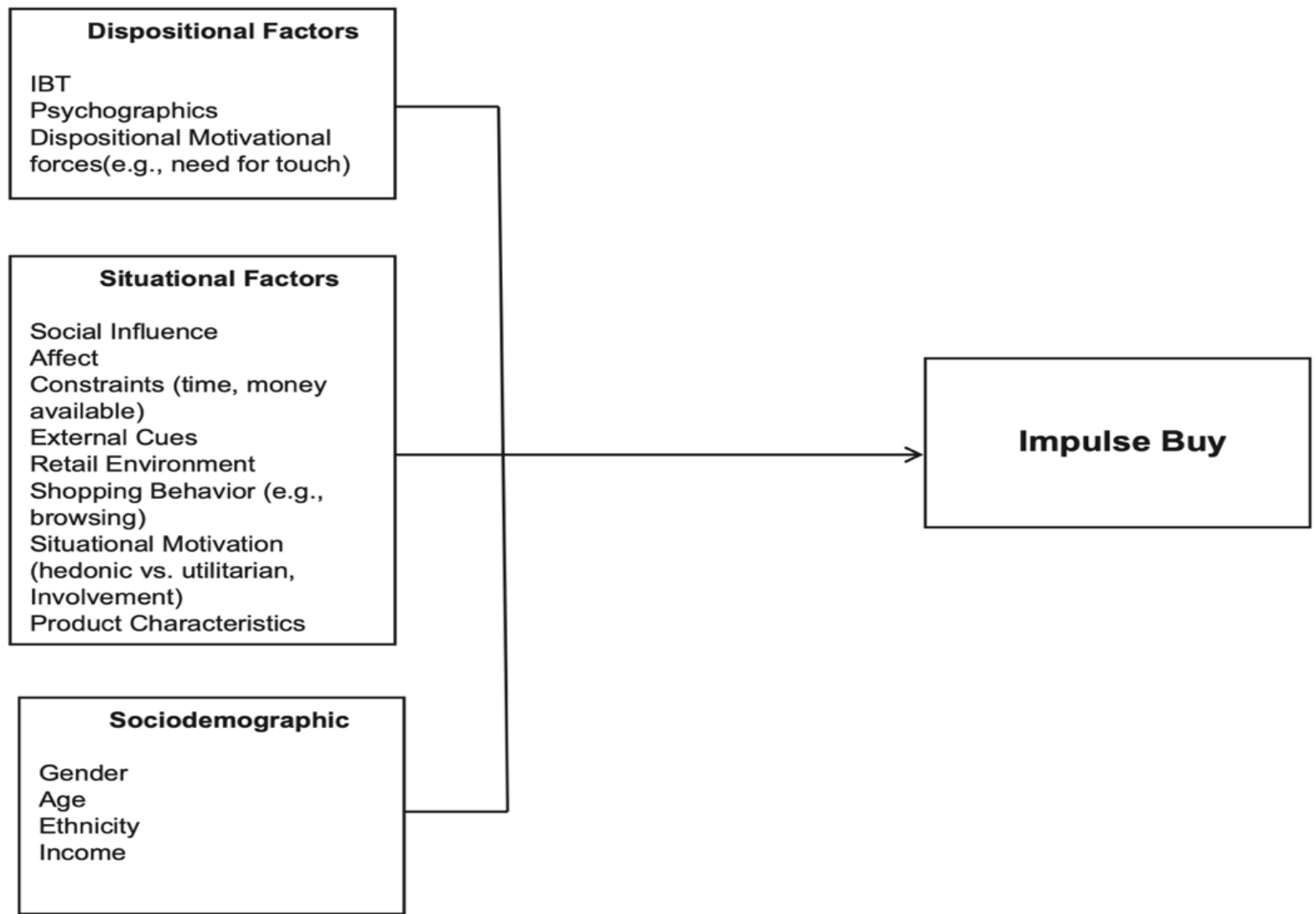

Figure 1. Factors influencing impulse buying by Amos et al. (2014)

Dispositional factors relevant to impulse buying include psychological constructs and impact buying behavior (Amel, Maachou, \& Elyas, 2014). As illustrated in Figure 1, psychological dimensions such as shopping delight, openness, sensitivity to influence, desire for cognition, and so on, are some dispositional antecedents relating to impulse buying (P. Sharma et al., 2010b).

On the other hand, situational antecedents are external stimuli, events, or the conditions consumers find themselves in when they generate impulsive desires (Beatty \& Ferrell, 1998; Dholakia, 2000; Kacen, Hess, \& Walker, 2012). This can be sensory cues in a shopping area, a person's present state of being, or others' presence throughout a consumer's purchasing journey 
(Amos et al., 2014). Situational factors are generally outside the direct control of consumers; however, they straightforwardly influence the probability of an impulse purchase. Marketing execution, shopping environment, affective states, time limitations or financial worries, and social considerations are popular situational elements explored in the literature regarding the impulse buying phenomenon (Amos et al., 2014). The last category that has a considerable association with impulse buying is socio-demographic factors, which involve age, gender, income, and ethnicity.

As an extension to the studies by Amos et al. (2014) that mainly concentrated on major determinants of impulse buying, the latest meta-analysis from Iyer et al. (2020) (Figure 2) reclassified the factors and inserted various mediators and moderators of this phenomenon, in order to provide a more comprehensive understanding.

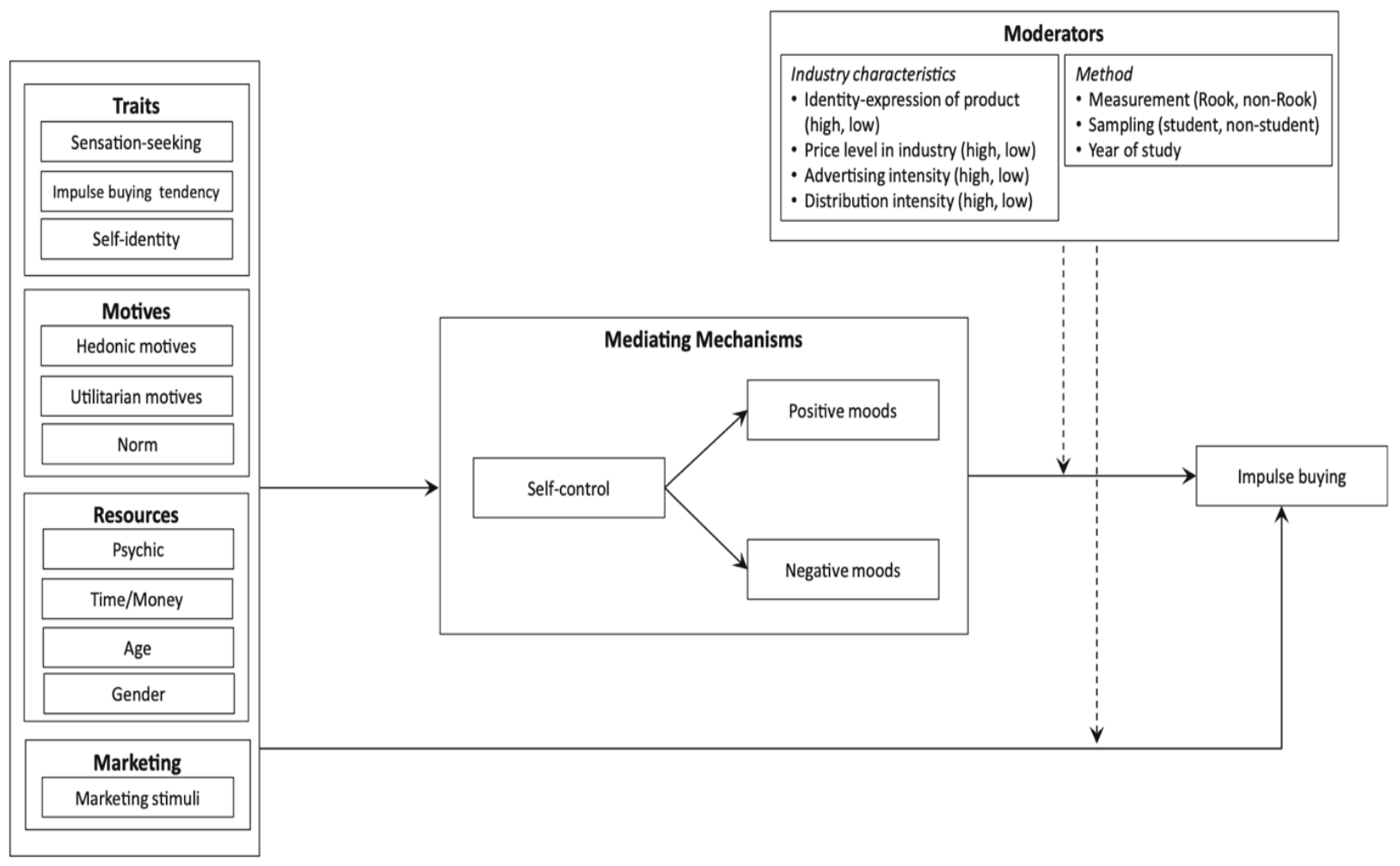

Figure 2. Factors influencing impulse buying by Iyer et al. (2020)

\subsubsection{External stimuli and the impact on impulse buying}

When a customer exposed to external stimuli, including store environment, marketingmix stimuli, demographics, and socio-economic factors, he or she will respond by buying or not buying impulsively (Amanda \& Brigitte, 2003; Virvilaitė, Saladienė, \& Žvinklytè, 2011; Youn $\&$ Faber, 2000). In the empirical studies, researchers are particularly interested in the relationship between external environmental stimuli such as atmospheric cues, in-store promotions, human factors, social interactions, and impulse buying behavior (Kotler, 1973; P. Sharma, Sivakumaran, \& Marshall, 2006). External determinants are categorized by four elements: namely Sensory cues, Visual merchandizing, Salespeople, and Social stimuli.

Sensory cues refer to atmospheric cues composed of smell, sights, sound, and touch that can have a profound impact on impulse buying behavior (Mattila \& Wirtz, 2001; P. Sharma et al., 2006; P. Sharma, Sivakumaran, \& Marshall, 2010a). Atmospherics is related to the ambient environment 
elements surrounding the customers that create the shopping atmosphere, including tangible and intangible cues. The tangible variables include fixtures, store cleanliness, theme colors, merchandise display, and attractive decoration, while intangible aspects are including temperature, scent, lighting, and music. These elements have a high possibility of affecting the impulse buying of the shoppers when engaging in buying decisions (Maymand \& Ahmadinejad, 2011).

Visual merchandizing or visual presentation is the means presented at the point of purchase to show the image, product quality, and value of the store. Regarding the case of clothing stores, the role of visual stimuli is to enhance the image of the store and boost sales (Bhatti \& Latif, 2014). Visual merchandizing dimensions are examined through both the store exterior (window display, façade, and retail premises) and the store interior, such as signage, layout, presentation techniques, ambient conditions, point of purchase display, floor merchandising, and shop brand name (Zhou \& Wong, 2003).

Salespeople play an essential role in influencing customer impulse purchase. Friendly, courteous, professional, knowledgeable, and supportive staff who offer extraordinary customer service appear crucial to trigger impulse purchases during their store visit (Mattila \& Wirtz, 2008; Peck \& Childers, 2006).

Social stimuli involve the number, type, and behavior of people that appear within the store, including other buyers and salespeople (Robert, 2001), including crowded behavior, employee attitudes, and social interaction between consumers and salespeople that can stimulate impulse buying (Turley \& Milliman, 2000). Among these social stimuli, perceived crowding was found the most influential factor of impulse purchase (Miyuri, 2017). This means that the presence and interaction of other shoppers within the store can increase the possibility of impulse purchases.

\subsubsection{Internal stimuli and the impact on impulse buying}

Internal factors of impulse buying concentrate directly on the individuals. Thus, considering the internal cues is a critical factor when examining impulse buying behavior (Kacen $\&$ Lee, 2002). Internal factors of impulsive purchase examine the internal cues and characteristics of the individual that induce them in impulse purchase. Among internal cues, researchers usually highlight emotions, hedonic shopping value, product involvement and personal traits (Kacen \& Lee, 2002; Tigert, Ring, \& King, 1976). In addition, Agarwal (2015) proved that personal traits, including demographics such as gender, income can trigger impulse purchase. Thus, there are 02 important internal factors affecting impulse buying: Emotion and Hedonic value.

Emotion is the mental state that arises from evaluating events or thoughts of oneself (Wong \& Bagozzi, 2005). Emotion can be positive or negative, which affects the consumer decision-making process (Avinash \& Chinmaya, 2009; Scheier \& Carver, 1988). Positive emotions relevant to the store may also affect the impulsive buying process. In addition, the environmental stimuli influence consumers' emotional states, such as pleasure, arousal, and dominance, leading to a positive approach toward purchasing (Donovan, Rossiter, Marcoolyn, \& Nesdale, 1994). Interestingly, Verplanken and Herabadi (2001) revealed that impulsive buyers are more emotional than non-impulsive ones. As a result, consumers with positive emotions would spend more money when shopping and, hence, are more likely to make decisive decisions faster (Lee \& Yi, 2008). Therefore, consumer emotion can be an important determinant to predict the impulse buying of the shoppers while engaging in buying fashion goods (Beatty \& Ferrell, 1998; Cobb \& Hoyer, 1986). 
Hedonic value is a body of consumer value that can be categorized as utilitarian value and hedonic value considered by marketers as essential factors to evaluate consumers' consumption experience to design their marketing effectively by a set of dimensions and items. Utilitarian consumers behave rationally while hedonic consumers seek the sensation perceived from enjoyment from their shopping experience (Yu \& Bastin, 2010). In this sense, possessing a product is not even the main purpose to purchase (Babin, Darden, \& Griffin, 1994). In the empirical literature, hedonic shopping value is measured by elements such as novelty, fun, praises from others, escapism, and social interaction. Most importantly, hedonic shopping value is found a predictor of impulse purchase (Ramanathan \& Menon, 2006; Rook, 1987).

The table below chronologically summarizes some key various results contributions to impulse buying.

\section{Table 2}

Chronological summary of the contribution of impulse buying

\begin{tabular}{|c|c|c|}
\hline Author & Year & Contribution \\
\hline Clover & 1950 & $\begin{array}{l}\text { First to study impulse buying mix and pointed out that some product } \\
\text { categories are more sold on impulse }\end{array}$ \\
\hline Stern & 1962 & $\begin{array}{l}\text { Defined impulse buying behavior by classifying it as planned, unplanned, } \\
\text { or impulse, also suggested that some product-related factors that might } \\
\text { predict impulse buying }\end{array}$ \\
\hline $\begin{array}{l}\text { Kollat and } \\
\text { Willett }\end{array}$ & 1969 & $\begin{array}{l}\text { Argued that consumer's characteristics and demographics influence the } \\
\text { impulse purchases }\end{array}$ \\
\hline $\begin{array}{l}\text { Rook and } \\
\text { Hoch }\end{array}$ & 1985 & $\begin{array}{l}\text { Argued that impulsive shoppers tend to enjoy shopping more, and the } \\
\text { impulse is the result of consumer's sensation and perception driven by the } \\
\text { environmental stimulus }\end{array}$ \\
\hline Rook & 1987 & $\begin{array}{l}\text { Introduced the concept of consumer impulsion as a lifestyle trait, which } \\
\text { can be linked to materialism, sensation seeking, and recreational aspects } \\
\text { of shopping }\end{array}$ \\
\hline $\begin{array}{l}\text { Rook and } \\
\text { Gardner }\end{array}$ & 1993 & $\begin{array}{l}\text { Defined impulse buying as an unplanned purchase that is characterized by } \\
\text { relatively rapid decision-making, and a subjective bias in favor of } \\
\text { immediate }\end{array}$ \\
\hline $\begin{array}{l}\text { Beatty and } \\
\text { Ferrell }\end{array}$ & 1998 & $\begin{array}{l}\text { Formulated the definition of Impulse buying as a sudden and immediate } \\
\text { purchase with no pre-shopping intentions either to buy the specific } \\
\text { product category or to fulfill a specific buying task }\end{array}$ \\
\hline $\begin{array}{l}\text { Youn and } \\
\text { Faber }\end{array}$ & 2000 & $\begin{array}{l}\text { Suggested that both positive and negative feeling states of consumer are } \\
\text { potential motivators for impulse buying }\end{array}$ \\
\hline $\begin{array}{l}\text { Kacen and } \\
\text { Lee }\end{array}$ & 2002 & $\begin{array}{l}\text { Described that cultural forces could impact impulse purchasing of } \\
\text { Individuals. People having Independent self-concept engage more in } \\
\text { impulse buying }\end{array}$ \\
\hline $\begin{array}{l}\text { Mattila and } \\
\text { Wirtz }\end{array}$ & 2008 & $\begin{array}{l}\text { Found that store environmental stimuli such as social factors (perceived } \\
\text { employee friendliness) positively affect impulse buying behavior }\end{array}$ \\
\hline \begin{tabular}{|l|} 
Yu and \\
Bastin \\
\end{tabular} & 2010 & $\begin{array}{l}\text { Hedonic shopping value of an individual lead to impulse purchases and } \\
\text { are inextricably related to each other }\end{array}$ \\
\hline $\begin{array}{l}\text { Maymand } \\
\text { and }\end{array}$ & 2011 & $\begin{array}{l}\text { Fixtures, store cleanliness, theme colors, merchandise display, and } \\
\text { attractive decoration, temperature, scent, lighting, and music has a high }\end{array}$ \\
\hline
\end{tabular}




\begin{tabular}{|l|l|l|}
\hline \multicolumn{1}{|c|}{ Author } & Year & \multicolumn{1}{c|}{ Contribution } \\
\hline Ahmadinejad & & possibility affecting the impulse buying of the shoppers \\
\hline $\begin{array}{l}\text { Dong-Jenn, } \\
\text { Huang, and } \\
\text { Feng }\end{array}$ & 2011 & $\begin{array}{l}\text { Discounted offerings, attractive advertisement as well as special gifts, } \\
\text { loyalty programs, etc. are found positively correlated with impulse buying } \\
\text { behavior }\end{array}$ \\
\hline Amos et al. & 2014 & $\begin{array}{l}\text { Three requirements are satisfied will an impulse purchase occur: } \\
\text { unplanned and accompanied by a pleasant surge of emotions, gratifying } \\
\text { the individual's needs }\end{array}$ \\
\hline Agarwal & 2015 & $\begin{array}{l}\text { Proved that personal traits, including demographic such as gender, income } \\
\text { can trigger impulse purchase }\end{array}$ \\
\hline Miyuri & 2017 & $\begin{array}{l}\text { Perceived crowding was found the most influential factor of impulse } \\
\text { purchase }\end{array}$ \\
\hline Tran & 2020 & \begin{tabular}{l} 
Changing context of society opened out various ways of defining the term \\
\hline
\end{tabular} \\
\hline
\end{tabular}

Source: Collected and summarised by the authors

\subsubsection{Impulse buying and Corporate Social Responsibility (CSR)}

Despite the fact that there has been a tremendous amount of research on impulsive buying behavior's determinants, studies regarding the relationship between this phenomenon and CSR - the field that receives considerable attention from consumers and businesses in this day and age, are overlooked. There are severely limited studies on this particular association, for example, the study of Hayat, Jianjun, Zameer, and Iqbal (2020) about the influence of three dimensions of CSR, including environmental, social, and economic well-being on impulse buying. According to the study's findings, though environmental and economic well-being are found to have a positive impact on consumers' impulse buying, social well-being is uninfluential to this buying pattern. Notwithstanding, since the study was restricted to three CSR practices and trust as the only mediator, this calls for further investigations on other mediating variables well as aspects of CSR. Additionally, the research scope is relatively modest as it is centered in China, which essentially means that any future studies aiming at other contexts such as developing countries such as Vietnam may provide greater clarity to the association between two variables while also fulfilling the existing research gap.

\section{Discussions}

The results show that Corporate Social Responsibility (CSR) has been studied for years and changed the ways corporates doing business. For instance, ethical responsibility is also needed to be performed by corporations to make contributions to society. Previous studies have indicated numerous benefits that corporations can reap from CSR campaigns (Joireman et al., 2015). Companies can earn more competitive advantages by promoting, executing CSR activities, and satisfying the needs and expectations of the organization's stakeholders, including shareholders and customers. This eventually brings higher value for the company (Wang \& Li, 2016), and thus, CSR has become a major strategy for the sustainable development of every organization (C. Y. Chung et al., 2018). Also, by employing good CSR campaigns, firms can enhance the brand image and reputation, improve customer satisfaction and customer loyalty (Wu et al., 2016). With regard to the relationship between CSR and impulse buying, current studies have shown that there is a paucity of relevant empirical research works. This calls for further exploration in order to fill in the missing knowledge (research gap) and extend the scholarship of these interesting research fields.

The study has some limitations. Firstly, due to the researchers' restraining time, that could affect the quality of work. Secondly, the limitation of resources such as "good and strong 
e-library" also restrains the ability for searching journal articles with high ranking and more updated reading materials.

The authors propose some future research directions. First, extensive work on literature review needs to be conducted across all the aspects of CSR and impulse buying behavior. From that work, empirical studies should be conducted to explore the impacts of CSR activities on the unplanned purchase of Vietnamese consumers, especially the Generation Z (Gen Z, from 20 - 30 years old) since this young generation is worth to be further explored due to their huge consumption power and special identities. Moreover, due to the uncertainty of the society (e.g., the Covid 19 pandemic), future studies should pay attention to the online implementation of CSR and the impacts on impulse buying that young netizens experiencing while purchasing online. It is certainly that e-commerce will soon be a key driver of the Vietnamese economy, leading to more online impulsive buying among young consumers (namely Gen $\mathrm{Z}$ ) who are becoming more tech-savvy, care more about Internet-based CSR activities.

\section{References}

Agarwal, V. (2015). A study of demographic factors influence on consumers' impulse purchase behavior. CLEAR International Journal of Research in Commerce \& Management, 6(11), 59-62. Retrieved March 10, 2021, from http://search.ebscohost.com/login.aspx?direct= true $\& \mathrm{db}=\mathrm{bth} \& \mathrm{AN}=119728811 \&$ site $=$ ehost-live \&scope $=$ site

Amanda, C., \& Brigitte, B. (2003). Gender differences in cognitive and affective impulse buying. Journal of Fashion Marketing \& Management, 7(3), 282-295.

Amel, G., Maachou, D. E. K., \& Elyas, S. (2014). Exploring women motivations toward impulse buying behavior in Algeria. Romanian Journal of Marketing, (2), 30-37.

Amos, C., Holmes, G. R., \& Keneson, W. C. (2014). A meta-analysis of consumer impulse buying. Journal of Retailing and Consumer Services, 21(2), 86-97.

Aragoncillo, L., \& Orus, C. (2018). Impulse buying behaviour: An online-offline comparative and the impact of social media. Spanish Journal of Marketing-ESIC, 22(1), 42-62. doi:10.1108/SJME-03-2018-007

Avinash, K., \& Chinmaya, K. (2009). Consumers' perceptions: An analytical study of influence of consumer emotions and response. Direct Marketing: An International Journal, 3(3), 186-202. doi:10.1108/17505930910985134

Babin, B. J., Darden, W. R., \& Griffin, M. (1994). Work and/or fun: Measuring hedonic and utilitarian shopping value. Journal of Consumer Research, 20(4), 644-656.

Baron, D. P. (2001). Private politics, corporate social responsibility, and integrated strategy. Journal of Economics \& Management Strategy, 10(1), 7-45.

Beatty, S. E., \& Ferrell, M. E. (1998). Impulse buying: Modeling its precursors. Journal of Retailing, 74(2), 169-191.

Bhatti, K. L., \& Latif, S. (2014). The impact of visual merchandising on consumer impulse buying behavior. Eurasian Journal of Business and Management, 2(1), 24-35.

Carroll, A. (1979). A three-dimensional conceptual model of corporate performance. Academy of Management Review, 4(4), 497-505.

Carroll, A. (2015). Corporate Social Responsibility (CSR) is on a sustainable trajectory. Journal of Defense Management, 5(2), 1-2. 
Chang, Y.-H., \& Yeh, C.-H. (2017). Corporate social responsibility and customer loyalty in intercity bus services. Transport Policy, 59, 38-45. doi:10.1016/j.tranpol.2017.07.001

Chung, C. Y., Jung, S., \& Young, J. (2018). Do CSR activities increase firm value? Evidence from the Korean market. Sustainability, 10(9), 1-22.

Chung, K.-H., Yu, J.-E., Choi, M.-G., \& Shin, J.-I. (2015). The effects of CSR on customer satisfaction and loyalty in China: The moderating role of corporate image. Journal of Economics, Business and Management, 3(5), 542-547.

Clover, V. T. (1950). Relative importance of impulse buying in retail stores. Journal of Marketing, 15(1), 66-70. doi:10.2307/1247083

Cobb, C. J., \& Hoyer, W. B. (1986). Planned versus impulse purchase behavior. Journal of Retailing, 62(4), 384-409.

Coley, A., \& Burgess, B. (2003). Gender differences in cognitive and affective impulse buying. Journal of Fashion Marketing \& Management, 7(3), 282-295. doi:10.1108/13612020310484834

Creasey, D. (2015). Corporate responsibility: You can't afford to ignore it. Governance Directions, 67(3), 161-163.

Dholakia, U. M. (2000). Temptation and resistance: An integrated model of consumption impulse formation and enactment. Psychology \& Marketing, 17(11), 955-982.

Donaldson, L. (1990). The ethereal hand: Organizational economics and management theory. Academy of Management Review, 15(3), 369-381.

Dong-Jenn, Y., Huang, K. C., \& Feng, X. (2011). A study of the factors that affect the impulsive cosmetics buying of female consumers in Kaohsiung. International Journal of Business and Social Science, 2(24), 275-282.

Donovan, R. J., Rossiter, J. R., Marcoolyn, G., \& Nesdale, A. (1994). Store atmosphere and purchasing behavior. Journal of Retailing, 70(3), 283-294.

DuPont, D. (1965). Consumer buying habits studies. Wilmington, DE: Du Pont De Nemours and Company.

Friedman, M. (1970). A theoretical framework for monetary analysis. Journal of Political Economy, 78(2), 193-238.

Gardner, M. P., \& Rook, D. W. (1988). Effects of impulse purchases on consumers' affective states. ACR North American Advances, 15(1), 127-130.

Hameed, F., Qayyum, A., \& Awan, Y. (2018). Impact of dimensions of CSR on purchase intention with mediating role of customer satisfaction, commitment and trust. Pakistan Business Review, 20(1), 13-30.

Hategan, C.-D., Sirghi, N., Curea-Pitorac, R.-I., \& Hategan, V.-P. (2018). Doing well or doing good: The relationship between corporate social responsibility and profit in Romanian companies. Sustainability, 10(4), Article 1041.

Hayat, K., Jianjun, Z., Zameer, H., \& Iqbal, S. (2020). Understanding the influence of corporate social responsibility practices on impulse buying. Corporate Social Responsibility and Environmental Management, 27(3), 1454-1464.

Hopkins, M. (2004). Corporate social responsibility: An issues paper (Working Paper No. 27). Retrieved January 01, 2004, from International Labour Office website: https://www.ilo.org/integration/resources/papers/WCMS_079130/lang--en/index.htm 
Hu, Y., Chen, S., Shao, Y., \& Gao, S. (2018). CSR and firm value: Evidence from China. Sustainability, 10(12), Article 4597.

Iglesias, O., Markovic, S., Bagherzadeh, M., \& Singh, J. J. (2020). Co-creation: A key link between corporate social responsibility, customer trust, and customer loyalty. Journal of Business Ethics, 163(1), 151-166.

Iyer, G. R., Blut, M., Xiao, S. H., \& Grewal, D. (2020). Impulse buying: A meta-analytic review. Journal of the Academy of Marketing Science, 48(3), 384-404.

Joireman, J., Smith, D., Liu, R. L., \& Arthurs, J. (2015). It's all good: Corporate social responsibility reduces negative and promotes positive responses to service failures among value-aligned customers. Journal of Public Policy \& Marketing, 34(1), 32-49.

Jones, R., \& Murrell, A. J. (2001). Signaling positive corporate social performance: An event study of family-friendly firms. Business \& Society, 40(1), 59-78.

Kacen, J. J., \& Lee, J. A. (2002). The influence of culture on consumer impulsive buying behavior. Journal of Consumer Psychology, 12(2), 163-176.

Kacen, J. J., Hess, J. D., \& Walker, D. (2012). Spontaneous selection: The influence of product and retailing factors on consumer impulse purchases. Journal of Retailing and Consumer Services, 19(6), 578-588.

Keller, K. L. (1993). Conceptualizing, measuring, and managing customer-based brand equity. Journal of Marketing, 57(1), 1-22.

Kollat, D. T., \& Willett, R. P. (1969). Is impulse purchasing really a useful concept for marketing decisions? Journal of Marketing, 33(1), 79-83.

Kotler, P. (1973). Atmospherics as a marketing tool. Journal of Retailing, 49(4), 48-64.

Lee, G. Y., \& Yi, Y. (2008). The effect of shopping emotions and perceived risk on impulsive buying: The moderating role of buying impulsiveness trait. Seoul Journal of Business, 14(2), 67-92.

Luo, X., \& Bhattacharya, C. B. (2006). Corporate social responsibility, customer satisfaction, and market value. Journal of Marketing, 70(4), 1-18.

Malik, M. S., Ali, H., \& Ishfaq, A. (2015). Corporate social responsibility and organizational performance: Empirical evidence from banking sector. Pakistan Journal of Commerce and Social Sciences (PJCSS), 9(1), 241-247.

Mattila, A. S., \& Wirtz, J. (2001). Congruency of scent and music as a driver of in-store evaluations and behavior. Journal of Retailing, 77(2), 273-289.

Mattila, A. S., \& Wirtz, J. (2008). The role of store environmental stimulation and social factors on impulse purchasing. Journal of Services Marketing, 22(7), 562-567.

Maymand, M. M., \& Ahmadinejad, M. (2011). Impulse buying: The role of store environmental stimulation and situational factors (An empirical investigation). African Journal of Business Management, 5(34), Article 13057.

McWilliams, A., Siegel, D. S., \& Wright, P. M. (2006). Corporate social responsibility: Strategic implications. Journal of Management Studies, 43(1), 1-18.

Miyuri, S. (2017). Underdog effects: The role of consumption domain and retail crowding. Journal of Consumer Marketing, 34(5), 384-392. doi:10.1108/JCM-07-2016-1872 
Oh, S., Hong, A., \& Hwang, J. (2017). An analysis of CSR on firm financial performance in stakeholder perspectives. Sustainability, 9(6), Article 1023.

Park, E., Kim, K. J., \& Kwon, S. J. (2017). Corporate social responsibility as a determinant of consumer loyalty: An examination of ethical standard, satisfaction, and trust. Journal of Business Research, 76, 8-13.

Peck, J., \& Childers, T. L. (2006). If I touch it I have to have it: Individual and environmental influences on impulse purchasing. Journal of Business Research, 59(6), 765-769. doi:10.1016/j.jbusres.2006.01.014

Rahman, S. (2011). Evaluation of definitions: Ten dimensions of corporate social responsibility. World Review of Business Research, 1(1), 166-176.

Ramanathan, S., \& Menon, G. (2006). Time-varying effects of chronic hedonic goals on impulsive behavior. Journal of Marketing Research, 43(4), 628-641. Retrieved March 12, 2021, from http://doc-distant.univ-lille2.fr/login?url=http://search.ebscohost.com/ login.aspx?direct=true \&AuthType $=$ ip, uid $\& d b=b$ th $\& A N=22754663 \&$ site $=$ edslive $\&$ scope $=$ site

Robert, F. R. (2001). The role of values in servant leadership. Leadership \& Organization Development Journal, 22(2), 76-84. doi:10.1108/01437730110382631

Rook, D. W. (1987). The buying impulse. Journal of Consumer Research, 14(2), 189-199.

Rook, D. W., \& Gardner, M. P. (1993). In the mood: Impulse buying's affective antecedents. Research in Consumer Behavior, 6(7), 1-28.

Rook, D. W., \& Hoch, S. J. (1985). Consuming impulses. ACR North American Advances, 12(1), 23-27.

Scheier, M. F., \& Caver, C. S. (1988). A model of behavioral self-regulation: Translating intention into action. Advances in Experimental Social Psychology, 21, 303-346. doi:10.1016/S0065-2601(08)60230-0

Sen, S., \& Bhattacharya, C. B. (2001). Does doing good always lead to doing better? Consumer reactions to corporate social responsibility. Journal of Marketing Research, 38(2), 225-243.

Sharma, E. (2019). A review of corporate social responsibility in developed and developing nations. Corporate Social Responsibility and Environmental Management, 26(4), 712-720.

Sharma, P., Sivakumaran, B., \& Marshall, R. (2006). Investigating impulse buying and variety seeking: Towards a general theory of hedonic purchase behaviors. Advances in Consumer Research, 33(1), 388-389. Retrieved March 15, 2021, from http://search.ebscohost.com/ login.aspx?direct $=$ true $\& d b=b$ th $\& A N=23585745 \&$ site $=$ ehost-live

Sharma, P., Sivakumaran, B., \& Marshall, R. (2010a). Exploring impulse buying and variety seeking by retail shoppers: Towards a common conceptual framework. Journal of Marketing Management, 26(5/6), 473-494. doi:10.1080/02672570903485097

Sharma, P., Sivakumaran, B., \& Marshall, R. (2010b). Impulse buying and variety seeking: A trait-correlates perspective. Journal of Business Research, 63(3), 276-283.

Stern, H. (1962). The significance of impulse buying today. Journal of Marketing, 26(2), 59-62.

Tigert, D. J., Ring, L. J., \& King, C. W. (1976). Fashion involvement and buying behavior: A methodological study. Advances in Consumer Research, 3(1), 46-52. 
Tran, V. D. (2020). Assessing the relationship between perceived crowding, excitement, stress, satisfaction, and impulse purchase at the retails in Vietnam. Cogent Business \& Management, 7(1), Article 1858525.

Turley, L. W., \& Milliman, R. E. (2000). Atmospheric effects on shopping behavior: A review of the experimental evidence. Journal of Business Research, 49(2), 193-211. doi:10.1016/S0148-2963(99)00010-7

Verplanken, B., \& Herabadi, A. (2001). Individual differences in impulse buying tendency: Feeling and no thinking. European Journal of Personality, 15(S1), S71-S83.

Vidaver-Cohen, D., \& Brønn, P. S. (2015). Reputation, responsibility, and stakeholder support in Scandinavian firms: A comparative analysis. Journal of Business Ethics, 127(1), 49-64.

Virvilaite, R., Saladienè, V., \& Žvinklytè, J. (2011). The impact of external and internal stimuli on impulse purchasing. Economics \& Management, 16, 1329-1336.

Wang, K. T., \& Li, D. (2016). Market reactions to the first-time disclosure of corporate social responsibility reports: Evidence from China. Journal of Business Ethics, 138(4), 661-682.

Wong, N. Y., \& Bagozzi, R. P. (2005). Emotional intensity as a function of psychological distance and cultural orientation. Journal of Business Research, 58(4), 533-542. doi:10.1016/S0148-2963(03)00144-9

Wu, T.-J., Tsai, H.-T., \& Tai, Y.-N. (2016). Would corporate social responsibility affect consumers' attitudes towards brand and purchase behavior? Buyer-seller guanxi as the moderator. Revista de Cercetare si Interventie Sociala, 53, 272-287.

Youn, S., \& Faber, R. J. (2000). Impulse buying: Its relation to personality traits and cues. Advances in Consumer Research, 27(1), 179-185. Retrieved March 20, 2021, from http://doc-distant.univ-

lille2.fr/login?url=http://search.ebscohost.com/login.aspx?direct=true\&AuthType=ip,uid $\& \mathrm{db}=\mathrm{bth} \& \mathrm{AN}=6687575 \&$ site $=$ eds-live $\&$ scope $=$ site

Youn, S., \& Faber, R. (2002). The dimensional structure of consumer buying impulsivity: Measurement and validation. ACR North American Advances, 29(1), 280.

Yu, C., \& Bastin, M. (2010). Hedonic shopping value and impulse buying behavior in transitional economies: A symbiosis in the Mainland China marketplace. Journal of Brand Management, 18(2), 316-330. Retrieved March 25, 2021, from http://docdistant.univ-

lille2.fr/login?url=http://search.ebscohost.com/login.aspx?direct=true\&AuthType=ip,uid $\& \mathrm{db}=$ edsgao $\& \mathrm{AN}=$ edsgcl.241180671\&site=eds-live \&scope $=$ site

Zhou, L., \& Wong, A. (2003). Consumer impulse buying and in-store stimuli in chinese supermarkets. Journal of International Consumer Marketing, 16(2), 37-54. doi:10.1300/J046v 16n02_03 